\title{
Pengembangan Media Cergam Untuk Meningkatkan Minat Belajar Matematika Pada Siswa Sekolah Dasar di Daerah Tertinggal
}

\author{
Nopem Kusumaningtyas \\ FPIEK IKIP Budi Utomo Malang \\ nopem_kusumaningtyas@yahoo.co.id \\ Welas Listianingsih \\ FPIEK IKIP Budi Utomo Malang \\ welas_lnsih@yahoo.co.id
}

\begin{abstract}
Nowadays, the research on the production of mathematic learning media on the basis of technology is in progress. The purpose of the study is to produce the story media with pictures to improve the students' interest of learning mathematics. The model used was a procedural model development. Of the data collection based on the questionaires from the proper aspects of contents, language, presentation, and display, it indicated the good average score of 3.61 on Likert scale. In addition, based on the result of survey and experiment towards 20 students as sample at SDN Klampok III Singosari, the condition of the media of learning mathematics (CERGAM) can increase the students interest of reading and learning mathematics with score of 3.63 on the Likert scale from the criteria involving aspects of benefit, presentation, and display.
\end{abstract}

Keywords: media, picture, learning, mathematics, reading, CERGAM

Seiring dengan berkembangnya waktu, pengelolaan alat bantu pembelajaran berupa media sangat dibutuhkan untuk membantu proses belajar mengajar. Dengan menerapkan strategi dan media pembelajaran yang baik dapat membangkitkan minat dan motivasi siswa, baik berupa metode maupun pendekatan melalui alat bantu media dengan berlandaskan fase kegiatan pembelajaran (Kusumaningtyas, 2010:36).

Matematika merupakan ilmu pengetahuan abstrak, maka dalam mengajarkan matematika diperlukanmediapembelajaranyangmenjadikan matematika lebih mudah dipelajarai oleh peserta didik. Namun dari hasil wawancara peneliti, sebagian besar siswa sekolah dasar menganggap matematika mata pelajaran yang sulit. Kesulitan akan matematika, membuat siswa kurang minat untuk belajar matematika.

Saat ini berkembang penelitian tentang pembuatan media pembelajaran matematika berbasis teknologi yang menumbuhkan minat siswa belajar matematika. Memang penelitian ini merupakan terobosan baru bagi dunia pendidikan matematika, namun kenyataan di lapangan media pembelajaran berbasis teknologi belum sepenuhnya dapat diaplikasikan, terutama untuk daerah tertinggal. Seperti yang terjadi pada media hasil penelitian saya terdahulu, yaitu "media animasi untuk bahasan pecahan kelas V sekolah dasar", ternyata media tersebut tidak bisa diaplikasikan di sekolah yang terpencil, dikarenakan belum adanya saranaprasarana yang memadai.

Kita ketahui dari 398 kabupaten di Indonesia, 183 diantaranya merupakan daerah tertinggal (antaranews.com, 2011). Jika rata-rata setiap kapupaten terdapat 20 sekolah, maka ada 3660 sekolah yang tidak bisa menikmati media berbasis teknologi yang sangat inovatif tersebut. Sungguh sayang memang!

Untuk itu perlu diciptakannya media pembelajaran yang dapat di aplikasikan seluruh daerah di Indonesia. Pada penelitian saat ini, peneliti tertarik dengan media cerita bergambar. Mengapa cerita bergambar?

1. Penelitian ini, peneliti menggunakan tingkat sekolah dasar. Pada tingkat inilah mulai diberikan pengetahuan dan ketrampilan dasar yang memegang peranan penting dalam mempersiapkan siswa untuk 
$74 \mid$ Nopem Kusumaningtyas \& Welas Listianingsih, Pengembangan Media Cergam untuk ...

mengikuti jenjang pendidikan selanjutnya.

2. Gambar-gambar media cergam yang atraktif, dan berwarna menarik membuat anak tertarik untuk melihat dan membacanya.

3. Karakteristik cerita bergambar ringan, mudah di bawah kemana-mana, dan harga yang terjangkau, sehingga mudah diaplikasikan di setiap sekolah.

Dengan demikian urgensi (keutamaan) penelitian ini antara lain adalah:

1. terciptanya media cergam untuk pembelajaran Matematika bagisiswa sekolah dasar, yang diharapkan dapat meningkatkan minat siswa belajar Matematika dan dapat diaplikasikan di seluruh daerah .

2. meningkatnya minat belajar siswa setelah penggunaan media cergam pembelajaran matematika pada proses belajar mengajar yang sesungguhnya

Untuk itu peneliti, ingin menggunakan cerita bergambar atau disebut dengan CERGAM sebagai salah satu media pembelajaran yang dapat meningkatkan minat belajar matematika pada tingkat sekolah dasar di daerah tertinggal.

Dari uraian latar belakang diatas maka pada penelitian tahap pertama ini dapat dirumuskan permasalahan sebagai berikut bagaimana mengembangkan media CERGAM yang dapat meningkatkan minat belajar matematika siswa sekolah dasar di daerah tertinggal. Tujuan khusus penelitian ini adalah: menghasilkan media cerita bergambar (CERGAM) untuk meningkatkan minat belajar matematika pada siswa sekolah dasar di daerah tertinggal. Penelitian ini dilaksanakan dalam dua tahap, yang masing-masing tahapan mempunyai tujuan khusus yang lebih spesifik, diantaranya adalah:

Tujuan penelitian pada tahap I adalah mengembangkan produk media pembelajaran matematika berupa media CERGAM yang dapat meningkatkan minat belajar matematika siswa sekolah dasar di daerah tertinggal. Untuk mencapai tujuan tersebut peneliti menggunakan jenis penelitian pengembangan, Model pengembangan produk yang digunakan adalah model pengembangan prosedural. Keluaran akhir dari penelitian ini adalah media CERGAM untuk meningkatkan minat belajar matematika siswa sekolah dasar di daerah tertinggal.

\section{Media Pembelajaran}

Pengertian media menurut Gagne adalah berbagai jenis komponen dalam lingkungan siswa yang dapat merangsang siswa untuk belajar. Media adalah perantara atau pengantar pesan dari pengirim ke penerima pesan (Sadiman, 2007:6). Berbeda lagi dengan Santoso S. Hamijaya, yang berpendapat bahwa media adalah bentuk perantara yang dipakai orang penyebar ide, sehingga ide atau gagasan itu sampai pada penerima (Rohani, 1997 : 2).

Media dalam aktivitas pembelajaran dapat didefinisikan sebagai "sesuatu yang dapat membawa informasi dan pengetahuan dalam interaksi yang berlangsung antara siswa dan guru (Asnawir, 2004). Media yang dapat digunakan dalam pembelajaran biasanya disebut media pembelajaran. Menurut Hamalik (1994), media pembelajaran adalah alat, metode, dan teknik yang digunakan dalam rangka lebih mengefektifkan komunikasi dan interaksi antara guru dengan siswa dalam proses pembelajaran.

Arsyad (2007) mengatakan bahan media pembelajaran adalah alat bantu apa saja baik itu berupa visual atau verbal yang dapat menyampaikan atau mengantarkan pesanpesan pembelajaran yang dapat merangsang pikiran, perasaan, dan kemauan siswa sehingga dapat mendorong terjadinya proses belajar guna mencapai tujuan pembelajaran.

Berdasarkan definisi yang dikemukakan oleh para ahli diatas dapat disimpulkan bahwa media pembelajaran adalah pengantar pesan dari pengirim ke penerima pesan baik berupa visual atau verbal yang digunakan yang digunakan dalam rangka lebih mengefektifkan komunikasi dan interaksi antara guru dengan siswa dalam proses pembelajaran.

\section{CERGAM sebagai Media Pembelajaran Matema- tika}

Cerita bergambar merupakan sebuah kesatuan cerita disertai dengan gambar-gambar yang berfungsi sebagai penghias dan pendukung cerita yang dapat membantu proses pemahaman terhadap isi cerita tersebut. Menurut wikipedia the free encylopedia cerita bergambar adalah suatu bentuk seni yang menggunakan gambar-gambar tidak bergerak yang disusun sedemikian rupa sehingga membentuk jalinan cerita. Gambar 
adalah suatu bentuk ekspresi komunikasi universal yang dikenal khayalak luas. Melalui cerita bergambar diharapkan pembaca dapat dengan mudah menerima informasi dan diskripsi cerita yang hendak disampaikan.

Cergam dapat didefinisikan sebagai suatu bentuk kartun yang mengungkapkan karakter dan memerankan suatu cerita dalam urutan yang erat dihubungkan dengan gambar dan dirancang untuk memberikan hiburan kepada para pembaca. Adapun karakteristik cergam antara lain: (1) cergam terdiri atas berbagai situasi cerita bersambung, (2) cergam bersifat humor, (3) perwatakan lain dari cergam harus dikenal agar kekuatan medium ini bias dihayati, (4) cergam memusatkan perhatian di sekitar rakyat, (5) cerita pada cergam mengenai diri pribadi sehingga pembaca dapat segera mengidentifikasikan dirinya melalui perasaan serta tindakan dari perwatakan tokoh utamanya, (6) ceritanya ringkas dan menarik perhatian, (7) dilengkapi dengan aksi bahkan dalam lembaran surat kabar dan buku-buku, dan (8) cergam dibuat lebih hidup serta diolah dengan pemakaian warna - warna utama secara bebas (Sudjana, 2007:64).

Cergam umumnya berbentuk rangkaian gambar, masing-masing dalam kotak, yang keseluruhannya merupakan rentetan satu cerita. Gambar-gambar itu biasanya dilengkapi dengan balon-balon ucapan dan ada kalanya masih disertai narasi sebagai penjelasan. Cergam dimuat secara tetap sebagai cerita bersambung dalam majalah atau surat kabar atau diterbitkan sebagai buku.

Penggunaan media dapat mempermudah gurudalammenyampaikanmateripembelajaran. Tetapi guru perlu berhati-hati dalam memilih media dan mengorganisir pembelajaran. Sebab apabila terjadi koordinasi dan komunikasi yang kurang baik antara guru dan sisa dapat mengakibatkan siswa hanya bermain-main dalam belajar. Selain itu guru juga harus berhatihati sebab seringkali media dibuat bersifat komersil tanpa mempertimbangkan akibat yang ditimbulkannya.

Peranan pokok dari cergam dalam pembelajaran adalah kemampuannya dalam dalam menciptakan minat para siswa. Untuk itu dalam penggunaan media cergam secara efektif pada saat proses belajar mengajar, guru diwajibkan untuk menggunakan motivasi potensial dari buku cergam yang dipadu dengan metode mengajar, sehingga cergam akan dapat menjadi alat pengajaran yang efektif (Sudjana,2007:68). Dengan demikian cergam akan dapat difungsikan sebagai media instruksional edukatif. Penggunaan cergam dalam pengajaran sebaiknya dipadu dengan metode mengajar, sehingga cergam akan dapat menjadi alat pengajaran yang efektif.

\section{Efektivitas Pembelajaran}

Efektivitas menurut Ensiklopedia Nasional Indonesia (1997) berarti tercapainya suatu tujuan, suatu usaha dapat dikatakan efektif kalau usaha itu mencapai tujuannya. Secara ideal, efektivitas dapat dinyatakan dengan aturan yang pasti. Misalnya suatu usaha P mencapai 75\% efektif dalam mencapai tujuan Q. Jadi sesuatu dikatakan efektif jika mencapai tujuan yang telah tetap.

Sa'ud, Udin Saefudin. 2008. mengatakan bahwa dalam bidang pendidikan efektif dapat ditinjau dari dua segi yaitu segi efektif mengajar guru dan segi efektif belajar murid. Efektif mengajar guru terutama menyangkut jenis-jenis kegiatan belajar-mengajar yang direncanakan dapat dilaksanakan dengan baik. Efektif belajar murid terutama menyangkut tujuan-tujuan pembelajaran yang diinginkan melalui kegiatan belajar dan mengajar yang ditempuh.

Menurut Djamarah (2002) ketercapaian tujuan pembelajaran dapat dikategorikan menjadi beberapa kategori yaitu: Istimewa/ Maksimal, Baik Sekali/Optimal, Baik/Minimal, dan Kurang. Dengan kriterianya adalah sebagai berikut:

1. Istimewa/Maksimal : apabila seluruh $(100 \%)$ bahan pelajaran yang diajarkan dapat dikuasai oleh siswa

2. Baik Sekali/Optimal : apabila sebagian besar (76\%-99\%) bahan pelajaran yang diajarkan itu dapat dikuasai oleh siswa

3. Baik/Minimal : apabila hanya (60\%-75\%) bahan pelajaran yang diajarkan itu dapat dikuasai oleh siswa

4. Kurang : apabila bahan pelajaran yang diajarkan itu kurang dari $60 \%$ dapat dikuasai oleh sisa

Berdasarkan tujuan pembelajaran tersebut maka suatu kegiatan pembelajaran dikatakan memiliki tingkat efektivitas yang baik bila dapat mencapai minimal $60 \%$ dari tujuan-tujuan pembelajaran yang ditetapkan 


\section{Daerah Tertinggal}

Saat ini Indonesia terdiri398 Kabupaten yang tersebar di 33 propinsi. (Wikipedia ensikopedia bebas). Menteri Percepatan Daerah Tertinggal (PDT), Ir H Ahmad Helmy Faishal Zaini, mengatakan bahwa jumlah daerah tertinggal di Indonesia saat ini telah mencapai angka sebanyak 183 kabupaten dari 33 provinsi yang tersebar di Tanah Air. Dari total daerah tertinggal yang jumlahnya mencapai 183 kabupaten, sekitar 70 persen berada pada wilayah Kawasan Timur Indonesia (KTI) dengan jumlah 128 kabupaten, sedangkan 30 persen masih berada pada Kawasan Barat Indonesia (KBI) dengan jumlah hanya 55 kabupaten," (Priyambodo RH, 2011: antaranews.com)). Kriteria daerah tertinggal itu antara lain adalah skala perekonomian masyarakat yang rendah, kualitas sumber daya manusia yang rendah, infrasturtur yang kurang memadai, kemampuan keuangan daerah untuk pembangunan di bawah Rp 140 miliar, dan aksesibilitas dan karakteristik daerah yang kurang mendukung.

Sebanyak tujuh kabupaten di Jawa Timur dinyatakan masuk kategori daerah tertinggal. Sekretaris Daerah Provinsi Jawa Timur Rasiyo, Jumat (25/6), mengatakan ke tujuh daerah itu adalah Kabupaten Sampang, Pamekasan, Bondowoso, Situbondo, Pacitan, Trenggalek, dan Kabupaten Madiun (dalam Rohman hadi, 2011, tempo.com). Untuk itu dalam penelitian ini, peneliti menggunakan sekolah di 7 kabupaten tersebut.

\section{METODE}

\section{Jenis Penelitian}

Penelitian berjudul "Pengembangan Media Cergam Untuk Meningkatkan Minat Belajar Pada Siswa Sekolah Dasar Di Daerah Tertinggal" dilaksanakan dalam dua tahap. Pada tahap I untuk menghasilkan produk menggunakan jenis penelitian pengembangan, Setelah dihasilkan sebuah produk dilanjutkan dengan jenis penelitian eksperimen, yang melibatkan kelompok eksperimen dan kelas kontrol. Penelitian Eksperimen ini akan dilaksanakan pada tahap kedua.

\section{Rancangan Penelitian}

\section{Rancangan Penelitian Tahap I}

Rancangan penelitian yang akan digunakan pada tahap I adalah rancangan penelitian dan pengembangan digunakan untuk mengembangkan produk yaitu media cergam untuk siswa sekolah dasar di daerah tertinggal.

Model pengembangan produk yang digunakan adalah model pengembangan prosedural. Model prosedural adalah model bersifat deskriptif yang menggariskan langkahlangkah yang harus diikuti untuk menghasilkan produk (Rusijono \& Mustaji, 2008:43). Sebab dalam mengembangkan media cergam juga berisi langkah-langkah pengembangan dari tahap awal sampai terciptanya produk cergam. Dalam tahapan ini langkah-langkah yang dilaksanakan dalam kegiatan penelitian dan pengembanganini terdiri dari persiapan kegiatan pengembangan, mengembangkan produk, uji coba produk, revisi produk, dan kajian produk yang sudah direvisi. Berikut uraian dari setiap tahapan:

\section{a. Kegiatan Awal Pengembangan}

Kegiatan awal pengembangan media cergam pembelajaran Matematika adalah
1) Konsultasi dan Diskusi dengan Ahli Materi
2) Konsultasi dan Diskusi dengan ahli Media
3) Persiapan kegiatan pengembangan,
Persiapan yang dilakukan sebelum pelaksanaanpenelitiandanpengembangan antara lain persiapan alat dan peraga yang akan membantu pelaksanaan kegiatan penelitian.

\section{b. Penyusunan Produk}

Berdasarkan data-data yang diperoleh dari survey lapangan, konsultasi dengan ahli materi dan ahli media dengan mengacu pada dasar-dasar teori atau konsep dan hasil-hasil penelitian terdahulu, maka peneliti menyusun draft awal cergam yaitu:
1) Menentukan tema
2) Membuat alur cerita
3) Membuat tokoh sesuai tema
4) Membuat dialog
5) Membuat gambar sesuai tema

\section{c. Validasi Ahli Materi dan Media Pembelajaran}

Validasi oleh ahli materi dan media pembelajaran dilakukan dengan meknisme memberikan media Cergam yang sudah jadi lalu para ahli memberikan penilaian terhadap media tersebut dalam bentuk 
angket. Jumlah ahli materi 4 orang dan jumlah media pembelajaran 2 orang.

d. Uji Coba Produk

Uji coba produk dilakukan untuk mengumpulkan data dalam rangka menguji kualitas media cergam pembelajaran matematika untuk siswa sekolah dasar yang dikembangkan. Subyek uji coba produk adalah anak sekolah dasar.

e. Revisi Produk

Berdasarkan hasil uji coba selanjutnya dilakukan revisi media cergam pembelajaran matematika untuk siswa sekolah dasar

f. Mengkaji Produk

Setelah dilakukan revisi produk awal selanjutnya dilakukan kajian dan membahas terhadap media cergam untuk pembelajaran Matematika bagi siswa sekolah dasar yang telah dibuat.

\section{Analisis Data}

Data yang diperoleh pada tahap I berupa data kualitatif yang berasal dari hasil uji coba perorangan dan lapangan, maka dianalisis dengan analisis deskriptif. Dalam proses ujicoba atau validasi media CERGAM dikembangkan dalam kelompok kecil, diberikan alat pengumpul data berupa skal likert. Skor yang diperoleh dengan menggunakan skala likert ini kemudian diberi rerata. Untuk keperluan analis, maka masing-masing jawaban yang diperoleh diberi skor sebagai berikut:Sangat baik (4),Baik (3), Cukup (2),Kurang (1),Sangat Kurang (0).

\section{HASIL}

\section{Validasi Ahli Materi dan Media pembelajaran}

Validasi oleh ahli materi dan media pembelajaran dilakukan dengan mekanisme memberikan hasil media Cergam yang sudah jadi lalu ahli media memberikan penilaian terhadap media tersebut dalam bentuk angket isian. Jumlah ahli materi sebanyak 4 orang danjumlah ahli media sebanyak 2 orang. Angket kepada ahli materi dan media pembelajaran berisi tentang : 1) Kelayakan isi 2) bahasa, 3) Sajian dan 4) Tampilan dari ahli media pembelajaran dirangkum pada tabel 1 .

Tabel 1 menunjukkan bahwa skor presentase aspek kelayakan isi, bahasa, sajian, dan tampilan adalah sebesar 90.83\%, 89.58\%, 89.17\%, 91.67\%, maka media CERGAM yang dikembangkan dapat dikategorikan sangat baik sehingga layak untuk digunakan sebagai media pembelajaran

\section{Uji coba Kepada Siswa Sekolah Dasar}

Setelah media CERGAM matematika mendapat validasi dari ahli materi dan media pembelajaran maka langkah selanjutnya adalah melakukan uji coba media CERGAM ini kepada siswa sekolah dasar. Mekanisme yang dilakukan adalah dengan memberikan media CERGAM pada siswa sekolah dasar yang telah dipilih dan meminta mereka untuk membacanya.

Setelah siswa melihat dan membaca media Cergam tersebut maka dilakukan pengukuran terhadap media ini dengan memberikan angket yang diisi oleh siswa. Dari hasil angket yang diberikan didapatkan hasil rata-rata .

Tabel 1 Penilaian Ahli Materi dan Media Pembelajaran

\begin{tabular}{ccccc}
\hline No & Aspek & Jumlah Butir & Rata-rata Skor & Prosentase \\
\hline 1 & Kelayakan Isi & 5 & 3,63 & 90.83 \\
2 & Bahasa & 4 & 3.58 & 89.58 \\
3 & Sajian & 5 & 3.56 & 89.17 \\
4 & Tampilan & 4 & 3.67 & 91.67 \\
& Total & 18 & 3.61 & 90.31 \\
\hline
\end{tabular}

Tabel 2 Nilai Angket Siswa SDN Klampok III Singosari

\begin{tabular}{ccccc}
\hline No & Aspek & Jumlah Butir & Rata-rata Skor & Prosentase \\
\hline 1 & Kemanfaatan & 5 & 3,66 & 91.50 \\
2 & Tampilan & 4 & 3.675 & 91.875 \\
3 & Sajian & 4 & 3.56 & 89.06 \\
& Total & 18 & 3.63 & 90.81 \\
\hline
\end{tabular}


78 | Nopem Kusumaningtyas \& Welas Listianingsih, Pengembangan Media Cergam untuk ...

Kriteria yang diberikan meliputi aspek kemanfaatan, tampilan, dan sajian. Skor rata-rata yang diperoleh yaitu sebesar 3.63 atau $90.81 \%$. Berdasarkan kriterria pada skala likert skor rata-rata ini dapat dikategorikan sangat baik sehingga dapat dikatakan bahwa Media Cergam ini memberikan ketertarikan yang sangat tinggi bagi anak sekolah dasar.

\section{PEMBAHASAN}

Media Cergam Matematika untuk anak sekolah dasar sudah dapat diimplementasikan sebagai salah satu media pembelajaran. Dari data yang diambil berdasarkan kuesioner dari aspek kelayakan isi, bahasa, sajian, dan tampilan diperoleh rata-rata yang sangat baik yaitu sebesar 3.61 pada skala likert. Hal ini menunjukkan bahwa media Cergam Matematika memberikan nilai tambah yang cukup signifikan pada siswa sekolah dasar sebagai media pembelajaran matematika.

Berdasarkan hasil survey dan ujicoba peneliti terhadap 20 sampel siswa SDN Klampok III Singosari keberadaan media Cergam Matematika dapat meningkatkan minat membaca dan mempelajari Matematika yang ditunjukkan dengan skor 3.63 pada skala likert dari kriteria yang meliputi aspek kemanfaatan, tampilan, dan sajian

Dari uraian diatas dapat disimpulkan bahwa media ini memberikan manfaat bagi siswa sekolah dasar untuk meningkatkan minat mereka mempelajari matematika.

\section{SIMPULAN}

Dari hasil pembuatan, pengujian, dan pembahasan diatas, maka dapat diambil kesimpulan sebagai berikut:

1. Media Cergam Matematika yang dikembangkan memnuhi criteria sangat baik berdasarkan penilaian ahli materi dan media yang di ukur berdasarkan dimensi kualitas yang meliputi aspek kelayakan isi, bahasa, sajian, dan tampilan diperoleh rata-rata yang sangat baik yaitu sebesar 3.61 pada skala likert sehingga layak digunakan sebagai media pembelajaran matematika

2. Respon siswa terhadap media cergam matematika yang dikembangkan sangat baik untuk meningkatkan mereka mempelajari Matematika yang ditunjukkan dengan skor 3.63 pada skala likert.

\section{SARAN}

Dari hasil penelitian dan pembahasan yang telah diuraikan dalam bab sebelumnya, maka dapat dirumuskan saran-saran sebagai berikut:

1. Perlu dilakukan pengembangan materi secara keseluruhan sehingga akan meningkatkan kualitas materi

2. Untuk mengetahui efektifitas dalam pembelajaran sistem e-learning adaptif yang telah dikembangkan tersebut, maka perlu dilakukan penelitian esperimen yang melibatkan pengguna yang sesungguhnya.

\section{Ucapan Terima Kasih}

Terselesaikannya penelitian ini tidak lepas dari bantuan dari berbagai pihak, oleh karena itu tidaklah berlebihan bila ucapan terima kasih dan penghargaan peneliti sampaikan kepada yang terhormat :

1. Direktorat pembinaan Penelitian dan Pengabdian Pada masyarakat, Direktorat Jendral Pendidikan Tinggi Departemen Pendidikan Nasional yang telah memberi kesempatan untuk melakukan penelitian ini.

2. Rektor IKIP Budi Utomo Malang yang telah memberikan bantuan moril dan materiil dalam pelaksanaan penelitian ini.

3. Kepala Pusat Penelitian dan Pengabdian (P2M) IKIP Budi Utomo Malang yang telah memberikan dorongan, bantuan dan fasilitas selama pelaksanaan penelitian ini

4. Dekan Fakultas Pendidikan Ilmu Eksakta dan Keolahragaan IKIP Budi Utomo Malang yang telah memberikan dukungan hingga terselesaikannya penelitian ini.

5. Kepala Sekolah SDN III Klampok Singosari Malang yang telah memberikan kesediaan untuk tempat uji coba penelitian

6. Bapak dan Ibu Guru SDN III Klampok Singosari telah banyak memberikan bantuan dan fasilitas selama pelaksanaan penelitian

7. Semua pihak yang telah membantu dalam pelaksanaan penelitian ini.

\section{DAFTAR PUSTAKA}

Arsyad, A. 2007. Media Pembelajaran. Jakarta: Raja Grafindo Persada.

Asnawir. 2004. Media Pembelajaran. Jakarta: Ciputat Press

Djamarah, S. B. 2002. Strategi Belajar Mengajar: PT. Rineka Cipta 
Ensuklopedia Nasional Indonesia. 1997. Jakarta: Delta Pamungkas

Hamalik, O. 1994. Media Pendidikan, Bandung: PT.Citra Aditya Bakti. Cet. Ke-7

Kusumaningtyas, N. 2010, Pengembangan Media Animasi untuk meningkatkan Hasil Belajar Matematika Pada Bahasan Pecahan Di SD Blimbing I Malang. Jurnal Paradigma, Tahun XV, No 30, JuliDesember 2010

Rohani, A. 1997. Media Instruksional Edukatif, Jakarta: PT. Rineka Cipta. Cet. Ke-1

Rohman, T., pada situs http://www.tempo. co/hg/ surabaya/2011/06/25 / brk,20100625-258411,id.html, diunduh 23 Juli 2011
Priyambodo, RH, pada situs http:// $\mathrm{w} \mathrm{w} \mathrm{w}$. a n t a r a n e w s.c o m / berita/1277542985/183-kabupatentermasuk-daerah-tertinggal-diindonesia, diunduh 2 Juli 2011

Rusijono dan Mustaji. 2008. Penelitian Teknologi Pembelajaran. Surabaya: Unesa University Press

Sadiman dkk, 2007. Media Pendidikan. Jakarta: Raja Grafindo Persada.

Sa'ud, U. S. 2008. Inovasi Pendidikan . Bandung: Alfabeta

Sudjana, N. Dan Ahmad, R. 2007, Media Pengajaran. Bandung: Sinar Baru Algesindo. 